\title{
Obituary
}

\section{Dr. V. K. Ting}

\section{$\mathrm{T}$} HE death of Dr. V. K. Ting on January 5 in hospital at Changsha, at the age of forty-eight years, removes the second of the three distinguished honorary directors of Cenozoic research in China, which was set up by the late Prof. Davidson Black with funds provided by the Rockefeller Foundation of New York, when the fundamental importance of the fossil bed found at Choukoutien was demonstrated. The Chinese Press has emphasised the fact that the death of this courageous and learned man is a national loss.

Dr. Ting was not only an enlightened pioneer who exerted great influence in promoting the development of science and its applications, but he was also keenly interested in doing what he could to promote peaceful relations between Great Britain and China. In the days when the restoration to China of the control of Hankow was under consideration, he went to Nanking to propose to his Government a scheme which would satisfy both British and Chinese demands, and was distressed when, after apparently reaching a satisfactory solution of the problem, the announcement was made in the House of Commons that Great Britain had given up Hankow. In spite of this action, which looked like a rebuff to him, he still retained his intense friendliness to the nation which had, in the persons of Prof. Davidson Black and Prof. J. W. Gregory, under whose influence he went to Glasgow, revealed its confidence in him. When, after much delay, the British Government decided to apply the Boxer Indemnity Fund to the same sort of purpose, the promotion of science and education, as the United States under the guidance of President Theodore Roosevelt had done, Dr. Ting was one of the Chinese advisors chosen by Sir Austen Chamberlain to help with his counsel.

After preliminary studies in Peiping, where he enjoyed the friendship of Dr. A. Grabau, who is professor of palæontology in the National University, Ting proceeded to Cambridge for study and then went to the University of Glasgow, where he was a devoted follower of Prof. J. W. Gregory, and obtained his B.Sc. He then undertook post-graduate research in the University of Freiburg and obtained his doctorate for it. Returning to China with the prestige of his German doctorate and much experience, he became active in shaping policy in the Ministry of Agriculture and Commerce, especially in promoting the development of mining. With this object, he and his friend, Wong Wen-Hao, recommended the Ministry to invite to China Dr. J. Gunnar Andersson, formerly director of the Swedish Geological Survey. Readers of NATURE are already familiar with the startling events which resulted from his inspired guidance in the fields of both palæontology and archæology. It was obvious that some medium for publication of the rich harvest of results accumulating from the researches of Prof. Davidson Black, Drs. Andersson, Ting and Wong was needed, and in co-operation with his distinguished colleagues, Dr. Ting founded Palceontologia Sinica with funds provided by Mr. Ivan Krueger. This journal played an essential part in the development of science in China, and particularly in making Sinanthropus known and appreciated.

While the growing Geological Survey under Dr. Wong's able direction was mainly concerned with the creation of palæontological knowledge, Dr. Ting never lost sight of the significance of mining for the industrial welfare of China, and he specially devoted himself to the study of mining, until eventually he met his death from coal-gas poisoning in the course of inspection of a mine in Hunan. How thoroughly he carried on this work is revealed by the fact that one of his friends, Mr. Sotsu King, an enthusiastic scientific amateur, founded a special institute for fuel research in Peiping, and equipped it for every kind of modern research on fuel problems. This is merely one example of how the late Dr. Ting used his knowledge and charm in the promotion of scientific progress.

The chief disaster ereated by th9 death of Dr. Ting is due to the removal of an essential link in the body of wise men, such as Dr. Hu Shih, Dr. Wong Wen-Hao and others who exert a vast and important influence by restraining the over-hasty adoption of the intoxicating elements of Western culture by an Oriental people. In the intellectual society of Peiping and the important work it is doing, the loss of Dr. Ting will be severely felt. Special sympathy must be extended to the students of the National University of Peiping who sit at the feet of Prof. Grabau, whose co-operation with Dr. Ting afforded an ideally wise guidance.

\section{Miss Marian Frost}

The death on December 27 of Miss Marian Frost, chief librarian and curator of the Public Library, Art Gallery and Museum at Worthing, at fifty-nine years of age, means that a delightful personality will be greatly missed by a large number of her friends and admirers of both sexes.

On her own initiative in 1902 Miss Frost communicated with Mr. Andrew Carnegie, and obtained his personal promise to assist Worthing in the way of a Public Library, and he granted $£ 5,000$ towards this. She was appointed chief librarian in 1896, and has since taken a prominent part in the educational and social life of Worthing. A fluent speaker, with a thorough knowledge of library and museum work, she was in great demand at the various conferences and other functions with which she became so 